\title{
Progress in stem cell-derived technologies for hepatocellular carcinoma
}

Rajagopal N Aravalli

Department of Radiology, University of Minnesota Medical School, Minneapolis, MN, USA
Correspondence: RN Aravalli Department of Radiology, University of Minnesota Medical School, MMC 292 Mayo, 420 Delaware Street SE, Minneapolis, MN 55455, USA

Tel + I 6126265550

Fax+l 6126265580

Email arava00I@umn.edu
This article was published in the following Dove Press journal:

Stem Cells and Cloning:Advances and Applications

30 April 2010

Number of times this article has been viewed

\begin{abstract}
Primary hepatocellular carcinoma (HCC) is a common malignancy that has a poor prognosis because it is often diagnosed at an advanced stage. HCC normally develops as a consequence of underlying liver disease and is most often associated with cirrhosis. Surgical resection and liver transplantation are the current best options to treat liver cancer. However, problems associated with liver transplantation, such as shortage of donors, risk of immune rejection, and tissue damage following surgery provided the impetus for development of alternative therapies. The emerging field of stem cell therapy has raised hopes for finding curative options for liver cancer. Stem cells have the ability not only to proliferate after transplantation but also to differentiate into most mammalian cell types in vivo. In this review, progress on
\end{abstract} stem cell-derived technologies for the treatment of liver cancer is discussed.

Keywords: liver, cancer, stem cell, therapy, hepatocellular carcinoma

\section{Introduction}

Primary liver cancer can be classified into one of several histologically different hepatic malignancies, including hepatocellular carcinoma (HCC), cholangiocarcinoma, hepatoblastoma, and hemangiosarcoma. ${ }^{1}$ Of these, $\mathrm{HCC}$ is the most common liver cancer, accounting for $70 \%-85 \%$ of cases, with nearly 700,000 deaths occurring worldwide each year. ${ }^{2,3}$ Recurrence or metastasis is quite common in patients who have had a resection, and survival rate is only $30 \%-40 \%$ at five years after surgery. ${ }^{4} \mathrm{~A}$ variety of risk factors may cause HCC which vary according to geographical region, ${ }^{5}$ and susceptibility to disease depends upon the host's genetic factors and pre-existing health conditions. ${ }^{6}$

During the past decade, advances in imaging techniques such as magnetic resonance imaging and contrast-enhanced ultrasonography with real-time low mechanical index harmonic imaging ultrasound equipment have allowed us to perform noninvasive diagnosis of HCC and replaced the need for invasive procedures like ultrasound-guided biopsy or angiography. ${ }^{7}$ Currently, in addition to standard chemotherapy, a number of treatment options are being used in the clinical setting. ${ }^{8}$ They include surgical resections such as enucleation, segmentectomy and lobectomy, percutaneous interventions such as hyperthermia and cryotherapy, transarterial interventions, and various embolization methods (chemical, thermochemical, and others). The treatment regimen that is currently being administered is shown in Figure 1. In addition to these treatment methods, efforts are being made to target cellular signaling pathways involved in HCC to suppress the tumors. Putative drug candidates for these studies include small-molecule protein kinase inhibitors, monoclonal antibodies, and antibiotics, either alone or in combinations. ${ }^{8,9}$ The most 


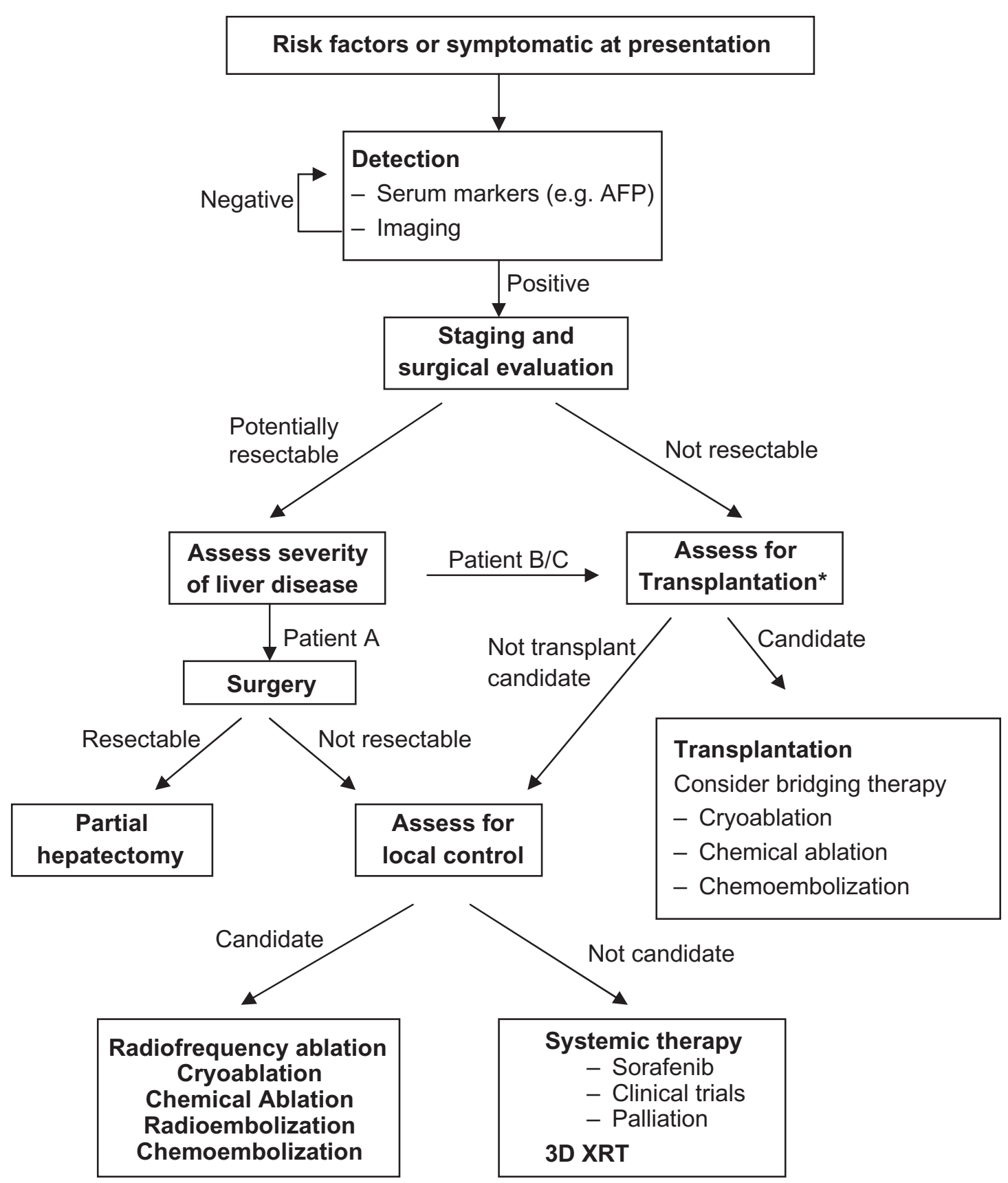

Figure I A general strategy for management of hepatocellular carcinoma based on tumor burden and the degree of liver disease. This algorithm depicts various treatment options that are used in the clinic depending upon the disease severity and the patient's previous medical history.

Note: *Molecular and genetic prognostic markers from biopsy specimens may potentially alter existing selection criteria

Abbreviations: AFP, alfa-fetoprotein; 3D XRT, three-dimensional conformal radiotherapy.

effective candidate among them is sorafenib, which showed a modest, three-month survival benefit in some patients. ${ }^{9}$ At present, sorafenib is the only drug approved by the Food and Drug Administration in the US for liver cancer. Prior to this, over 100 clinical trials of intravenous (IV) chemotherapy failed to show any statistically significant survival benefit in patients with HCC. ${ }^{10}$ For those patients fortunate enough to be identified, surgery is potentially curative. The shortage of donor livers for transplantation, however, has led to the development of techniques such as split liver transplantation and living donor transplantation. ${ }^{11}$ Currently, efforts are geared towards developing cell-based therapies where hepatocytes and stem/progenitor cells will be used for transplantation into damaged and diseased livers. Such transplanted cells could proliferate and repopulate the liver and eventually restore its functions. 


\section{Liver stem cells}

The liver is the only organ in the human body that is capable of renewing itself following the loss of the natural tissue. Even after $70 \%$ hepatectomy, this remarkable regenerative capacity is achieved due to the proliferation of hepatocytes and cholangiocytes, and other hepatic cells such as stellate cells, macrophages, and endothelial cells. ${ }^{12}$ Under special circumstances, stem/progenitor cells and bone marrow (BM) cells also contribute to this regeneration process. ${ }^{13}$ Stem/ progenitor cells are critical to the tissue restoration process because they are bipotent and can differentiate into the two primary cell types of the liver, ie, hepatocytes and biliary ductal cells (cholangiocytes). In addition to their role in liver regeneration, stem/progenitor cells are important for studies of organogenesis and liver development. ${ }^{5,14,15}$

To date, a number of different types of stem/progenitor cells have been successfully isolated from healthy and injured livers (adult and fetal) as well as from liver tumors. ${ }^{16-32}$ These include cells of human, rodent, canine, swine, and simian origins (Table 1). One such population of human liver stem cells was recently shown to contribute to the generation of liver parenchyma in severe combined immunodeficient mice. ${ }^{33}$ Among liver stem cells, the human hepatic progenitor cells (HPCs) are the best studied. Apart from adult and fetal livers, ${ }^{15,34-36}$ they have been isolated and characterized from liver specimens with severe hepatocellular necrosis, chronic viral hepatitis, and chronic alcoholic liver disease ${ }^{37}$ In normal adult liver, these cells are localized in biliary ductules (canals of Hering)

The rodent counterparts of HPCs are termed "oval cells" because of their characteristic ovoid nucleus. ${ }^{38-41}$ They are bipotential, ${ }^{42}$ and express cell surface markers such as Thy1.1, CD34, Flt3-receptor, and c-kit. ${ }^{43}$ They

Table I Liver stem/progenitor cells

\begin{tabular}{lll}
\hline Cell type/name & Species & Reference(s) \\
\hline Human progenitor cells & Human & $18,23,26,33,34$ \\
Oval cells & Rat & 31 \\
& Mouse & 25 \\
Stem/progenitor cells & Hamster & 17 \\
& Rat & 21 \\
& Mouse & $15,25,27,28$ \\
& Pig & 31 \\
& Monkey & 16 \\
Liver-derived progenitor cells & Dog & 20 \\
\hline
\end{tabular}

also produce alfa-fetoprotein (AFP), cytokeratin 19, and $\gamma$-glutamyl-transferase, and stain positive for one-cut 2 transcription factor (OC2), ovalbumin (OV-6), and BD1 when treated with monoclonal antibodies. Oval cells are normally isolated from the liver following treatment with agents such as 3,5-diethoxycarbonyl-1,4-dihydrocollidine (DDC), or from animals fed on choline-deficient diets and treated with 2-acetylaminofluorene (2-AAF). ${ }^{44,45}$ They proliferate in vivo following liver damage when the hepatocytes can no longer divide. ${ }^{46}$ In diseases such as alcoholic liver disease and during hepatitis $\mathrm{C}$ virus (HCV) infection, their numbers increase and correlate with the severity of the disease. ${ }^{47}$

Recently, Liu et al isolated epithelial progenitors from fetal rat livers that were able to divide in cell culture and express liver epithelial and biliary-specific markers. ${ }^{48}$ Upon differentiation in vitro, they also expressed albumin, CK-18 and AFP, and two weeks after transplantation into animals they were shown to display hepatocyte-like features in vivo. ${ }^{48}$ It has been proposed that certain epithelial cells in fetal and injured adult livers undergo epithelial-mesenchymal transition and home to liver parenchyma, and some of these cells may be capable of reversing this transition and become hepatocytes or cholangiocytes. ${ }^{49}$ This phenomenon of transition has been reported in a number of human diseases. $^{50}$

\section{Extrahepatic sources of liver stem cells}

In addition to these liver-derived stem/progenitor cells, many studies have been published demonstrating that cells of nonliver origin could also differentiate into "hepatocyte-like" cells (Figure 2). These cells could be a valuable source of hepatocytes and cholangiocytes. It is beyond the scope of this review to discuss every stem cell type that has been described, but those that have been well studied and successfully differentiated into hepatic cell types will be highlighted.

\section{Bone-marrow derived cells}

Mesenchymal stem cells (MSC) are multipotent stem cells derived from BM aspirates. They can be expanded readily in cell culture and can be induced to differentiate into many different cell types, including hepatic cells. ${ }^{51}$ These in vitro differentiated cells can express hepatocyte markers and possess hepatocyte-specific biochemical activities such as albumin secretion, urea production, and glycogen storage. ${ }^{52,53}$ It has been suggested that these BM-derived cells fuse with damaged hepatocytes after transplantation and change their 


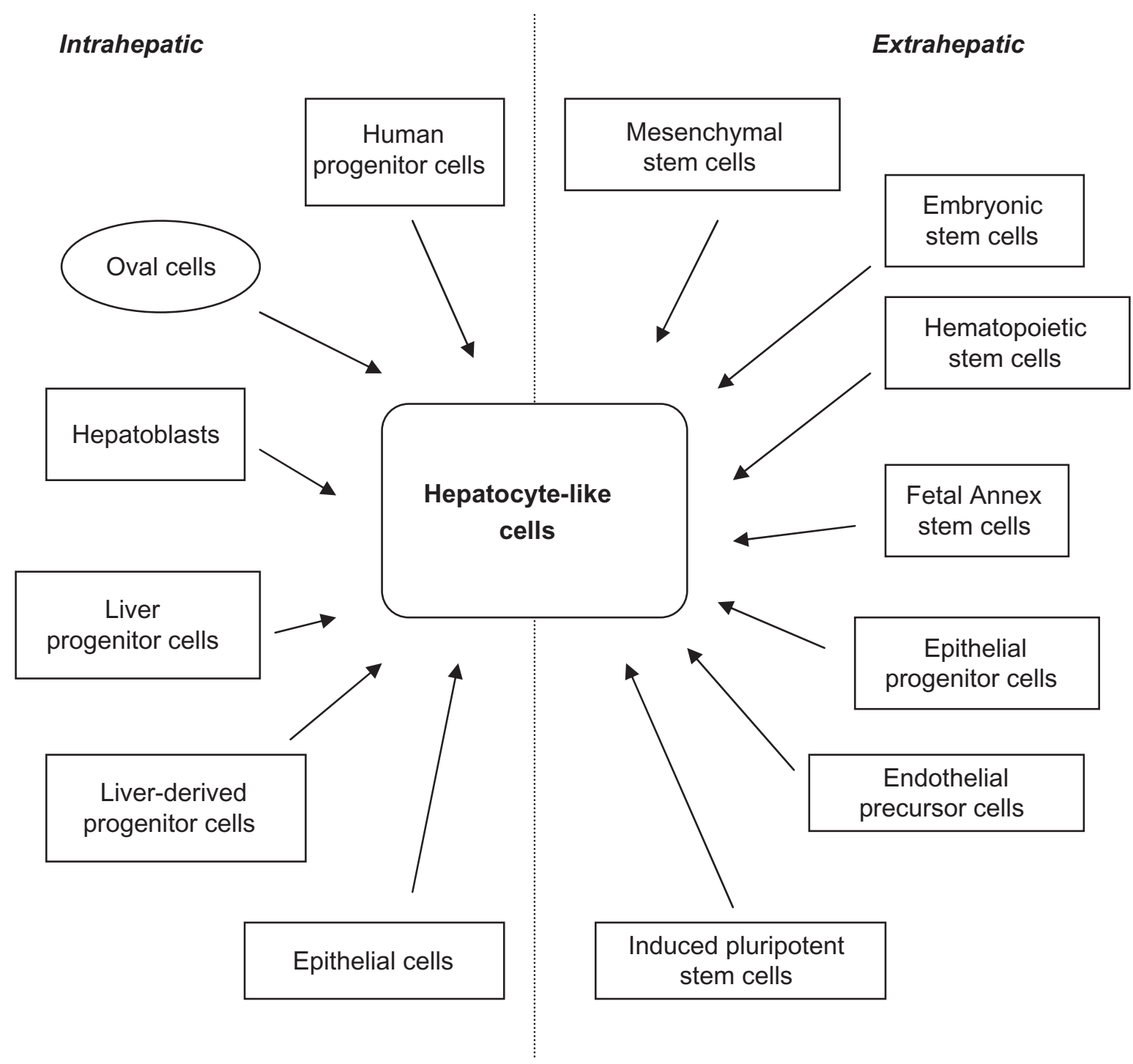

Figure 2 Intra- and extrahepatic sources of stem cells from different origins that have been demonstrated to differentiate into hepatocyte-like cells.

gene expression patterns to that of mature hepatocytes. . $^{41,54}$ Furthermore, implanted MSCs protect the liver by secreting soluble factors that possess antiapoptotic and promitotic properties, as shown in experiments with rats where hepatic failure was caused by D-galactosamine. ${ }^{55}$ In support of these studies, Lagasse et al showed that transplanted MSCs could differentiate into mature hepatocytes in vivo and rescue fumarylacetoacetate hydrolase-deficient mice. ${ }^{56}$ Transplanted MSCs were also demonstrated to restore liver function in albumin urokinase transgenic mice and in hepatitis B virus (HBV) transgenic mice.

Hematopoietic stem cells (HSC) are another type of stem cell present in the BM. They have the potential to differentiate into liver cells, both in vitro and in vivo, without fusion and could contribute to liver regeneration. ${ }^{57} \mathrm{~A}$ comparative study of the hepatocyte differentiation capacity of HSCs and MSCs in a rat model has shown that MSCs are more potent than HSCs in differentiating into hepatocytes. ${ }^{58}$

\section{Embryonic stem cells}

Embryonic stem cells (ESCs) are derived from the inner mass of an early-stage embryo known as the blastocyst. ${ }^{59}$ They are pluripotent and can be maintained in cell culture for prolonged periods of time without disturbing their developmental potential. ${ }^{60}$ In the early studies, embryonic stem cells from murine embryos were shown to differentiate into functional hepatocytes in vitro. ${ }^{61-63}$ Later it was shown that both murine- and human BM-derived MSCs could differentiate into hepatocytes both in vitro and in vivo. ${ }^{52,64}$ Several studies have shown that ESCs could be induced to differentiate into liver cells. 
For example, Hay et al differentiated human ESCs into hepatocyte-like cells by treating them with hepatocyte growth factor, ${ }^{65}$ and Ishizaka et al managed to differentiate mouse ESCs into hepatocytes by treating them with hepatocyte nuclear factor-3 $\beta .{ }^{66}$ Studies with BM transplant recipients have shown that these cells could home to liver and differentiate into normal hepatocytes. ${ }^{67,68}$ Because of major ethical concerns with the use and handling of ESCs, and due to difficulties in controlling their robust proliferative and differentiation potential, their use is currently limited to in vitro studies and to animal models.

\section{Fetal annex stem cells}

Umbilical cord blood contains multiple populations of pluripotent stem cells. Each of these populations can serve as a source of hepatocytes for liver regeneration. For instance, mesenchymal stromal cells isolated from the umbilical cord could be induced to differentiate into hepatocyte-like cells in cell culture after treating them with hepatocyte growth factor and fibroblast growth factor-4. ${ }^{69}$ Such differentiated cells express CK-18, AFP, and albumin. Similarly, umbilical cord matrix stem cells could also differentiate into hepatocyte-like cells. $^{70}$ In addition to these cells, human mononuclear cells from umbilical cord blood could differentiate into functional hepatocytes when transplanted in utero into fetal rats ${ }^{71}$ and into carbon tetrachloride $\left(\mathrm{CCl}_{4}\right)$-injured mouse liver. ${ }^{72}$

Placenta-derived stem cells are another source of hepatocytes. They can be expanded in cell culture for more than 20 populations. ${ }^{73}$ Recently, Chien et al cultured these cells from human placentae, differentiated them into hepatocytes, and examined their hepatocyte-specific functions. ${ }^{74}$ When compared with ESCs, there are no ethical issues involved in using these cells because the collection of placentae does not harm either the human mother or the infant. ${ }^{73}$

\section{Induced pluripotent stem cells}

The induced pluripotent stem cell (iPS) is an inducible cell type that can be generated by epigenetic reprogramming following induced expression of certain transcription factors. Takahashi and Yamanaka demonstrated this in a landmark study where they overexpressed four transcription factors Oct-3/4, Sox2, c-Myc, and Klf4 in mouse fibroblasts using a retrovirus to generate first iPS cells. ${ }^{75}$ In subsequent studies, Yamanaka et al and Yu et al demonstrated the generation of iPS cells from murine and human somatic cells. ${ }^{76,77}$ Recently, Si-Tayeb et al and Song et al reported the generation of human hepatocyte-like cells from iPS cells obtained from human ESCs. ${ }^{78,79}$ Hepatocyte-like cells produced in this procedure expressed various hepatic markers such as HNF-4a, FoxA2, AFP, and secreted albumin. Aoi et al isolated pluripotent stem cells from adult mouse liver and generated iPS cells by expressing these four transcription factors from a retrovirus in adult mouse hepatocytes and gastric epithelial cells. ${ }^{80}$ This finding suggests that functional hepatocytes and other liver cells can be reprogrammed to generate stem cells.

\section{Endothelial progenitor/precursor cells}

Endothelial precursor cells (EPCs) constitute a cell type that has the potential to differentiate into mature functional endothelial cells that form a capillary or line the lumen of a blood vessel. ${ }^{81}$ They were first isolated from a population of $\mathrm{CD}_{3} 4^{+}$peripheral mononuclear blood cells of the BM. ${ }^{82}$ Subsequently, they have been isolated from sources other than BM, such as the vessel wall. ${ }^{83}$ It has been reported that EPCs could differentiate into hepatocytes when cultured in hepatic differentiation media. ${ }^{84}$

\section{Others}

The adipose tissue contains MSCs that are multipotent and can be differentiated into functional hepatocyte-like cells by treatment with a cocktail of cytokines. ${ }^{85}$ In a recent study it was shown that, after transplantation, these human adipose tissue cells get incorporated into the liver parenchyma after transplantation into mice. ${ }^{86}$ After differentiation, they express a number of hepatocyte markers and biologic activities of liver cells. Recently, Ikeda et al showed that tooth germ progenitor cells derived from adipose tissue could prevent liver fibrosis and improve liver function after transplantation in rodents with liver injury caused by $\mathrm{CCl}_{4} \cdot{ }^{87}$ Other adipose tissue cells, such as salivary gland progenitor cells, differentiate into hepatocyte-like cells and express alpha-1 antitrypsin and albumin after transplantation into the murine liver via the portal vein. ${ }^{88} \mathrm{~A}$ novel cell type, the liver-derived progenitor cell, was recently discovered and isolated from healthy, uninjured rat livers. ${ }^{19}$

Based on these numerous reports of successful in vitro and in vivo hepatocyte-like differentiation of stem/progenitor cells isolated from different organs, it is predictable that other stem cells, such as amniotic epithelial cells ${ }^{89}$ and very small embryonic-like stem cells ${ }^{90}$ might also be induced to produce cells of hepatocyte and biliary lineages.

\section{Role of stem cells in liver cancer}

In the normal adult liver, there is little proliferation. However, following partial hepatectomy or injury, hepatocytes proliferate rapidly and repopulate the liver to restore its 
physical mass and physiologic functions. Initial experiments with rodents have demonstrated the ability of hepatocytes to proliferate and to populate the liver mass after partial hepatectomy. ${ }^{91,92}$ The data regarding the ability of human hepatocytes to undergo extensive cell division came from studies on chronic hepatitis with HCV and HBV. In the livers of patients with chronic viral hepatitis, there is an ongoing excessive hepatocyte death and compensatory proliferation. Based on the staining for cell proliferation markers, such as proliferating cell nuclear antigen and Ki-67, it was estimated that about $1 \%$ to $3 \%$ of hepatocytes die daily in the diseased liver, as opposed to $<0.01 \%$ in normal healthy livers. This excessive hepatocyte death obviously requires extensive proliferation to maintain a stable liver mass, suggesting that an individual hepatocyte would have to divide many times during the life of a patient with chronic hepatitis. Such prolonged self-replication in an inflammatory microenvironment could result in the accumulation of genetic lesions that cause cancer formation. ${ }^{93-95}$

Subsequent experiments with mouse urokinase plasmin ogen activator have shown that transplanted hepatocytes could regenerate the liver in its entirety after undergoing 12 rounds of replication. ${ }^{96}$ Serial transplantation of hepatocytes into fumarylacetoacetase hydrolase-deficient mice indicated that transplanted hepatocytes could divide at least 69 times in vivo, and when normal hepatocytes from wild-type mice are injected into these mutant mice, they colonized the mutant liver effectively. ${ }^{97}$ In another study, Laconi et al transplanted dipeptidyl peptidase IV (DPPIV)-positive cells into DPPIVdeficient F344 rats, and showed that transplanted cells could repopulate $40 \%$ to $60 \%$ of female rat livers within a year and $98 \%$ to $99 \%$ of hepatic mass in male rats within nine months after transplantation. ${ }^{98}$ Liu et al demonstrated that transplanted BM-derived EPCs could ameliorate the damage caused by $\mathrm{CCl}_{4}$ injury in rats. ${ }^{99}$ They transplanted EPCs into portal veins of female rats 12 weeks after treating the animals with $\mathrm{CCl}_{4}$ and found that EPCs home to the liver and regenerate into hepatocytes. In a similar study, Nakamura et al have showed that transplanted EPCs derived from BM could improve the outcome in a cirrhotic liver rat model. ${ }^{84}$ These findings demonstrate that the transplantation of hepatocytes and extrahepatic stem cells could be an effective treatment strategy to combat liver cancer.

Recent studies have demonstrated that the capacity to sustain tumor formation and growth resides in a small proportion of stem cells known as "cancer stem cells" (CSCs). ${ }^{100,101}$ They have a greater colony-forming efficiency, higher proliferation potential, and greater ability to form tumor in animal models. The identification of CSCs in a number of tissues including brain, ${ }^{102-104}$ prostate, ${ }^{105}$ breast, ${ }^{106}$ myeloid, ${ }^{107}$ gastric, ${ }^{108}$ colon, ${ }^{109,110}$ and lung ${ }^{111}$ reinforced the notion that stem cells might also exist in the liver. CSCs were later identified and isolated from the liver. ${ }^{12}$

The presence of CSCs and successful isolation of oval cells from cancerous tissue suggests that stem/progenitor cells play a key role in tumor formation in the liver. The clonality of HCC was later established, based on studies examining integration sites of HBV in tumor samples, ${ }^{113-115}$ as well as on the determination of restriction fragment length polymorphisms of X-linked genes such as the androgen receptor gene in tumor cells. ${ }^{116}$ However, the cell type that gives rise to $\mathrm{HCC}$ is not well understood as yet. ${ }^{117}$ In general, cell proliferation at the time of carcinogen exposure is a prerequisite for injury to the genome to take a heritable form. Therefore, it is logical to expect that the "target cell" has both the capacity to undergo extensive cell division and to remain viable for extended periods of time allowing for the accumulation of additional mutations needed for malignant transformation.

Additional evidence regarding the origin of HCC from hepatocytes comes from several studies done in rodents. In one such experiment, Gournay et al labeled hepatocytes with a retroviral vector expressing the $\beta$-galactosidase gene after two-thirds hepatectomy and fed the animals with 2-AAF to induce HCC. ${ }^{118}$ They later observed that some of the neoplastic nodules in the liver samples of these animals contained cells expressing $\beta$-galactosidase, indicating that they were directly derived from retrovirallylabeled hepatocytes. In another study, using similar retroviral marking of hepatocytes with $\beta$-galactosidase gene, Bralet et al showed that following chronic administration of diethyl-nitrosamine (DENA), some of the tumors that developed in the liver contained cells expressing $\beta$-galactosidase. confirming that mature hepatocytes can give rise to HCC in a clonal manner. ${ }^{119}$ While these studies demonstrated the capacity of resting hepatocytes to re-enter the cell cycle and divide in response to injury, others have showed that stem cells in the liver are also activated by injury. ${ }^{120,121}$ In fact, oval cells can generate hepatocytes and cholangiocytes when hepatocytes fail to respond after injury. ${ }^{42,122}$

The concept that oval cells and HPCs are involved in the development of HCC is based on numerous studies performed with animal models and with human clinical liver tumor specimens. Most models of hepatocarcinogenesis are characterized by very prominent proliferation of oval cells. One well-known example is the "Solt-Farber" model. ${ }^{123}$ 
In this model, DENA is administered first as an initiator, and after two weeks the animals were fed with 2-AAF to inhibit the proliferation of no initiated hepatocytes. Two-thirds partial hepatectomy was then performed in these animals to stimulate proliferation of cells that were initiated with DENA. The most prominent histologic feature observed in this model is proliferation of oval cells within biliary ductular structures, which peaked at 1-3 weeks, followed by the appearance of dysplastic nodules where oval cells surrounded the nodules, and migration into them. The development of HCC then occurred within 14 months in these rats. The comparison of the phenotypes between various cell populations has shown that tumor cells have a phenotype similar to that of oval cells but not hepatocytes. ${ }^{123}$

Another example of the experimental models supporting the involvement of progenitor/stem cells in hepatocarcinogenesis is the choline-deficient diet model. ${ }^{45}$ In this model, administration of the carcinogens ethionine or AAF to animals on a choline-deficient diet results in a rapid proliferation of oval cells beginning 1-2 days after the administration of the diet and results in tumor formation. Even though it is not clear whether oval cells or periductular progenitor cells are ultimately responsible for cancer formation, it is apparent that some type of hepatic progenitor cell, and not the mature hepatocyte, is the target for malignant transformation. The most direct evidence for the involvement of oval cells in hepatocarcinogenesis was provided by Dumble et al. ${ }^{124}$ This group isolated oval cells from $\mathrm{p} 53$ null mice and then transplanted them into athymic nude mice where the p53-deficient oval cells produced hepatocellular carcinomas, conclusively demonstrating the ability of oval cells to serve as the target cells of malignant transformation in HCC.

In another study, Yang et al used CD90 expression as a marker to characterize CSCs in HCC cell lines, tumor specimens, and blood samples. ${ }^{125}$ They showed that CD45-and CD90+ cells, but not CD90- cells, had tumorigenic potential in cell lines. All tumor specimens and most blood samples from HCC patients contained a population of $\mathrm{CD} 90^{+}$and $\mathrm{CD} 44^{-}$cells which were capable of generating tumor nodules when transplanted in immunodeficient mice. The $\mathrm{CD} 90^{+} \mathrm{CD} 44^{+}$cells demonstrated a more aggressive phenotype than the $\mathrm{CD} 90^{+} \mathrm{CD} 44^{-}$cells and formed metastatic lesions in the lungs of these mice. The gene expression profile of $\mathrm{CD} 45^{-} \mathrm{CD} 90^{+}$cells indicated a stem cell-like phenotype, and blockage of CD44 expression prevented the formation of local and metastatic tumor nodules, suggesting that CD44 be a viable target in the treatment for HCC.
HCC originating from hematopoietic progenitor cells was inferred from the observation that many HCC specimens contain a mixture of mature cells that were phenotypically similar to HPCs expressing OV-6, CK7, CK19, and chromogranin-A. This would suggest an origin from stem cells with partially and fully differentiated malignant progeny existing within the same tumor sample. ${ }^{126}$ Cells resembling HPCs have also been described in hepatoblastoma. ${ }^{32,127}$ Hepatoblastoma is generally thought to be stem cell-derived because both epithelial and mesenchymal tissue components can be found in such tumor specimens. ${ }^{128}$ Other studies have identified cells with an HPC phenotype in a rare subset of hepatic cancers. These tumors have two major components, ie, an HCC component and a cholangiocarcinoma component, suggesting that the tumor could originate from a bipotential progenitor cell. ${ }^{129}$ More recently, Zhang et al studied 12 cases of combined hepatocellular cholangiocarcinoma where the majority of the tumor cells expressed hepatic, biliary, as well as stem cell markers simultaneously, suggesting that these tumors were derived from HPCs. ${ }^{130}$

\section{Stem cell therapy for treatment of HCC}

Due to the problems associated with orthotopic liver transplantation, transplantation of hepatocytes has been proposed as an alternative treatment option for liver disease. However, widespread use of this approach is severely limited due to the shortage of reproducible sources of hepatocytes. ${ }^{131}$ As a result of this, as well as the emergence of the stem cell field, stem/progenitor cells with the capacity to differentiate into hepatocyte-like cells appear to be a promising curative option in liver disease. These cells could regenerate the liver mass because they can proliferate for prolonged periods of time and differentiate into hepatic cells after transplantation.

The most important implication of liver CSCs is their potential clinical impact in developing novel therapeutic approaches for HCC. Recently, several groups have reported isolation and characterization of human HCC stem cells. For example, CD133 has been reported to be a marker of CSCs in various tissues (brain, pancreas, prostate, colon) and to identify CSCs in hepatocellular carcinoma cell lines. ${ }^{27}$ They found that $\mathrm{HCC}$ was hierarchically organized and originated from a population of progenitor cells that expressed $\mathrm{CD} 133^{+}$. These progenitor cells also possessed characteristics similar to that of normal stem cells and the ability to self-renew and differentiate. In a follow-up study by the same researchers, it has been shown that $\mathrm{CD} 133^{+} \mathrm{HCC}$ stem cells were the cell 
population responsible for the chemotherapy (doxorubicin and 5-fluorouracil) resistance seen in HCC, and could be the source of tumor recurrence after chemotherapy. ${ }^{132}$ They also demonstrated that $\mathrm{CD} 133^{+} \mathrm{HCC}$ cells survived chemotherapy significantly better than most tumor cells which did not express CD133, and that the underlying mechanism was the constitutive activation of the serine/threonine protein kinase Akt and Bcl-2 cell survival pathways. An obvious clinical implication of this finding is the fact that specific inhibitors of these pathways would potentially be useful in the treatment of HCC.

The notion of CSCs initiating and advancing tumors is now well accepted in the scientific community. Unlike the great majority of cells in a given organ, only a small number of CSCs possess tumorigenic potential and the necessary phenotype of "stemness" to initiate tumors. ${ }^{133}$ Therefore, a critical step towards developing effective cancer treatments is to understand cellular, molecular, and biochemical differences between normal stem cells and CSCs. Knowledge of such differences would allow us to identify key targets for therapeutic applications. One common method that is being used to distinguish CSCs from other cells is identifying their expression of cell surface markers. Unfortunately, this approach has not been very useful because several of these surface markers are shared both by CSCs as well as normal stem cells of the corresponding tissue. For instance, both CSCs and normal stem cells of the liver express CD133. ${ }^{27,134-136}$ With the improvement in assays to determine gene expression profiles, it should be possible to identify the differences between the two cell types in the near future. Other approaches, such as studies of heritable epigenetic gene silencing, genetic alterations, and mutations in specific oncogenes of these cells, as well as the resident microenvironment of tumors, may allow us to understand the conditions that give rise to CSCs. Similarly, targeting specific cellular signaling pathways involved in HCC is another approach towards finding new treatments. ${ }^{5,8}$ Furthermore, removing the stemness of CSCs to eliminate their ability to proliferate and differentiate, and inhibiting their maintenance of stem cell state, is another approach that might provide us with important breakthroughs. ${ }^{137}$ It has been shown in a number of cancers that generation of tumors can be achieved by transplanting CSCs into animals. Therefore, transplantation of CSCs and stem/progenitor cells expressing oncogenes such as $c-M y c$ might allow us to develop animal models to study the disease process and to develop novel cancer therapies.

As discussed above, stem/progenitor cells have been isolated from almost every mammalian organ, and shown to differentiate into hepatocytes and other cell types. The important question is: are all these stem cells created equal? In other words, can we use stem cells from any organ for transplantation into livers for therapeutic purposes? To address this question, we need a clear understanding of the similarities and differences between various stem cells prior to and after their differentiation into the desired cell type. A couple of recent investigations have dealt with this issue. In one study, Sharova et al looked at the similarities and differences among mouse stem cells of different origins and strains using gene expression profiling. ${ }^{138}$ They found that ESCs and embryonic germ cells were indistinguishable in their gene expression pattern. Very few differences were observed when these cells were grown in normal growth medium and in the medium that promotes differentiation. However, using stringent statistical analysis and quantitative real-time polymerase chain reaction, the authors were able to identify a signature profile containing 20 genes that distinguish each cell type. Interestingly, the variation in gene expression was greater between ESCs and embryonic germ cells of different mouse strains than within a single strain. In another study, Noël et al evaluated global gene and protein expression profiling of human adipose tissue-derived and multipotential stromal cells using microarrays, 2D gel electrophoresis, and functional assays. They found that cell type-specific differences do exist between these cells, although they possess similar differentiation potentials. ${ }^{139}$ Their data suggest that stem cells are different and express genes depending upon their tissue origin. Further studies are needed to understand molecular mechanisms involved in the regulation of stemness and differentiation.

\section{Conclusions}

Advances in stem cell technology provide opportunities to develop novel approaches with an ability to reduce the morbidity and mortality associated with liver cancer. Liver cancer is a multifactorial disease with many different underlying pathogenic mechanisms caused by a variety of risk factors. Despite enormous progress during the past several decades, patient survival remains very low. Prospective, randomized human clinical trials are expensive, time-consuming, and very difficult to perform. A severe shortage of livers for orthotopic transplantation has compounded this problem even further. Unfortunately, hepatocyte transplantation has achieved little success in humans so far and there is a greater need to isolate and enrich stem cells with greater clonogenic potential to use them for therapy. ${ }^{117}$ However, stem cell therapy for the treatment of liver cancer is a long way away from reality. Rather than using treatments such as tetrosine, which are clinically unacceptable, 
enhancing the clonogenic potential of stem/progenitor cells isolated from healthy livers might prove critical for creating novel cancer therapeutics. Towards this goal, a better understanding of the molecular mechanisms involved in tumor formation and progression, development of new antifibrotic agents, experimental animal models that closely mimic the human disease, and antiviral agents are critical for the success of cell-based therapies for liver cancer.

\section{Disclosure}

The author reports no conflict of interest in this work.

\section{References}

1. Leenders MW, Nijkamp MW, Borel Rinkes IH. Mouse models in liver cancer research: A review of current literature. World J Gastroenterol. 2008;14:6915-6923.

2. El-Serag HB, Rudolph KL. Hepatocellular carcinoma: Epidemiology and molecular carcinogenesis. Gastroenterology. 2007;132:2557-2576.

3. Farazi PA, DePinho RA. Hepatocellular carcinoma pathogenesis: From genes to environment. Nat Rev Cancer. 2006;6:674-687.

4. Blum HE. Hepatocellular carcinoma: Therapy and prevention. World J Gastroenterol. 2005;11:7391-7400.

5. Aravalli RN, Steer CJ, Cressman ENK. Molecular mechanisms of hepatocellular carcinoma. Hepatology. 2008;48:2047-2063.

6. El-Serag H, Rudolph KL. Hepatocellular carcinoma: Epidemiology and molecular carcinogenesis. Gastroenterology. 2007;132:2557-2576.

7. Piscaglia F, Bolondi L. Recent advances in the diagnosis of hepatocellular carcinoma. Hepatol Res. 2007;37:S178-S192.

8. Aravalli RN, Cressman ENK. Molecular signaling in hepatocellular carcinoma. Cancer Chemother Rev. 2009;4:157-164.

9. Skelton M, O’Neill B. Targeted therapies for hepatocellular carcinoma. Clin Adv Hematol Oncol. 2008;6:209-218.

10. Thomas M, O'Beirne JP, Furuse J, Chan ATC, Abou-Alfa G, Johnson P. Systemic therapy for hepatocellular carcinoma: Cytotoxic chemotherapy, targeted therapy and immunotherapy. Ann Surg Oncol. 2008;15:1008-1014.

11. Gruessner B. Living Donor Organ Transplantation. New York, NY: McGraw Hill; 2008.

12. Michalopoulos GK. Liver regeneration: Alternative epithelial pathways. Int J Biochem Cell Biol. September 27, 2009. [Epub ahead of print].

13. Fausto N. Liver regeneration and repair: Hepatocytes, progenitor cells, and stem cells. Hepatology. 2004;39:1477-1487.

14. Aravalli RN, Steer CJ, Sahin MB, Cressman ENK. Stem cell origins and animal models of hepatocellular carcinoma. Dig Dis Sci. June 10, 2010. [Epub ahead of print].

15. Zhou QJ, Xiang LX, Shao JZ, et al. In vitro differentiation of hepatic progenitor cells from mouse embryonic stem cells induced by sodium butyrate. J Cell Biochem. 2007;100:29-42.

16. Allain JE, Dagher I, Mahieu-Caputo D, et al. Immortalization of a primate bipotent epithelial liver stem cell. Proc Natl Acad Sci U S A. 2002;99:3639-3644.

17. Lee JH, Rim HJ, Sell S. Heterogeneity of the "oval-cell” response in the hamster liver during cholangiocarcinogenesis following Clonorchis sinensis infection and dimethylnitrosamine treatment. J Hepatol. 1997;26:1313-1323.

18. Masson NM, Currie IS, Terrace JD, Garden OJ, Parks RW, Ross JA. Hepatic progenitor cells in human fetal liver express the oval cell marker Thy-1. Am J Physiol Gastrointest Liver Physiol. 2006;291:G45-G54.

19. Sahin MB, Schwartz RE, Buckley SM, et al. Isolation and characterization of a novel population of progenitor cells from unmanipulated rat liver. Liver Transpl. 2008;14:333-345.
20. Arends B, Vankelecom H, Vander Borght S, et al. The dog liver contains a "side population" of cells with hepatic progenitor-like characteristics. Stem Cells Dev. 2009;18:343-350.

21. Hirata M, Amano K, Miyashita A, Yasunaga M, Nakanishi T, Sato K. Establishment and characterization of hepatic stem-like cell lines from normal adult rat liver. J Biochem. 2009;145:51-58.

22. Spagnoli FM, Amicone L, Tripodi M, Weiss MC. Identification of a bipotential precursor cell in hepatic cell lines derived from transgenic mice expressing cyto-Met in the liver. J Cell Biol. 1998;143: 1101-1112.

23. Dan YY, Riehle KJ, Lazaro C, et al. Isolation of multipotent progenitor cells from human fetal liver capable of differentiating into liver and mesenchymal lineages. Proc Natl Acad Sci U S A. 2006;103: 9912-9917.

24. Duret C, Gerbal-Chaloin S, Ramos J, et al. Isolation, characterization, and differentiation to hepatocyte-like cells of nonparenchymal epithelial cells from adult human liver. Stem Cells. 2007;25:1779-1790.

25. Fougère-Deschatrette $C$, Imaizumi-Scherrer $T$, Strick-Marchand $H$, et al. Plasticity of hepatic cell differentiation: Bipotential adult mouse liver clonal cell lines competent to differentiate in vitro and in vivo. Stem Cells. 2006;24:2098-2109.

26. Nowak G, Ericzon BG, Nava S, et al. Identification of expandable human hepatic progenitors which differentiate into mature hepatic cells in vivo. Gut. 2005;54:972-979.

27. Ma S, Chan KW, Hu L, et al. Identification and characterization of tumorigenic liver cancer stem/progenitor cells. Gastroenterology. 2007;132:2542-2556.

28. Strick-Marchand H, Morosan S, Charneau P, Kremsdorf D, Weiss MC. Bipotential mouse embryonic liver stem cell lines contribute to liver regeneration and differentiate as bile ducts and hepatocytes. Proc Natl Acad Sci U S A. 2004;101:8360-8365.

29. Zhou H, Rogler LE, Teperman L, Morgan G, Rogler CE. Identification of hepatocytic and bile ductular cell lineages and candidate stem cells in bipolar ductular reactions in cirrhotic human liver. Hepatology. 2007;45:716-724.

30. Haruna Y, Saito K, Spaulding S, Nalesnik MA, Gerber MA. Identification of bipotential progenitor cells in human liver development. Hepatology. 1996;23:476-481.

31. Tokiwa T, Yamazaki T, Ono M, Enosawa S, Tsukiyama T. Cloning and characterization of liver progenitor cells from the scattered cell clusters in primary culture of porcine livers. Cell Transplant. 2008;17: 179-186.

32. Fiegel HC, Gluer S, Roth B, et al. Stem-like cells in human hepatoblastoma. J Histochem Cytochem. 2004;52:1495-1501.

33. Herrera MB, Bruno S, Buttiglieri S, et al. Isolation and characterization of a stem cell population from adult human liver. Stem Cells. 2006;24:2840-2850

34. Haque S, Haruna Y, Saito K, et al. Identification of bipotential progenitor cells in human liver regeneration. Lab Invest. 1996;75:699-705.

35. Weiss TS, Lichtenauer M, Kirchner S, et al. Hepatic progenitor cells from adult human livers for cell transplantation. Gut. 2008;57: 1129-1138.

36. Rao MS, Khan AA, Parveen N, Habeeb MA, Habibullah CM, Pande G. Characterization of hepatic progenitors from human fetal liver during second trimester. World J Gastroenterol. 2008;14:5730-5737.

37. Roskams TA, Libbrecht L, Desmet VJ. Progenitor cells in diseased human liver. Semin Liver Dis. 2003;23:385-396.

38. Menthena A, Deb N, Oertel M, et al. Bone marrow progenitors are not the source of expanding oval cells in injured liver. Stem Cells. 2004;22:1049-1061.

39. Petersen BE, Bowen WC, Patrene KD, et al. Bone marrow as a potential source of hepatic oval cells. Science. 1999;284:1168-1170.

40. Sirica AE, Mathis GA, Sano N, Elmore LW. Isolation, culture, and transplantation of intrahepatic biliary epithelial cells and oval cells. Pathobiology. 1990;58:44-64.

41. Wang X, Willenbring H, AkkariY, et al. Cell fusion is the principal source of bone-marrow-derived hepatocytes. Nature. 2003;422:897-901. 
42. Lázaro CA, Rhim JA, Yamada Y, Fausto N. Generation of hepatocytes from oval cell precursors in culture. Cancer Res. 1999;58:5514-5522.

43. Petersen B, Goff JP, Greenberger JS, Michalopoulos GK. Hepatic oval cells express the hematopoietic stem cell marker Thy- 1 in the rat. Hepatology. 1998;27:433-445.

44. Sell S. Liver stem cells. Mod Pathol. 1994;7:105-112.

45. Shinozuka H, Lombardi B, Sell S, Iammarino RE. Early histological and functional alterations of ethionine liver carcinogenesis in rats fed a choline-deficient diet. Cancer Res. 1978;38: 1092-1098.

46. Sell S. The role of progenitor cells in repair of liver injury and in liver transplantation. Wound Repair Regen. 2001;9:467-482.

47. Lowes KN, Brennan BA, Yeoh GC, Olynyk JK. Oval cell numbers in human chronic liver diseases are directly related to disease severity. Am J Pathol. 1999;154:537-541.

48. Liu YN, Zhang J, He QH, Dai X, Shen L. Isolation and characterization of epithelial progenitor cells from human fetal liver. Hepatol Res. 2008;38:103-113.

49. Choi SS, Diehl AM. Epithelial-to-mesenchymal transitions in the liver. Hepatology. 2009;50:2007-2013.

50. Baum B, Settleman J, Quinlan MP. Transitions between epithelial and mesenchymal states in development and disease. Semin Cell Dev Biol. 2008:19:294-308.

51. Jiang Y, Jahagirdar BN, Reinhardt RL, et al. Pluripotency of mesenchymal stem cells derived from adult marrow. Nature. 2002;418:41-49.

52. Lee KD, Kuo TK, Whang-Peng J, et al. In vitro hepatic differentiation of human mesenchymal stem cells. Hepatology. 2004;40: $1275-1284$

53. Schwartz RE, Reyes M, Koodie L, et al. Multipotent adult progenitor cells from bone marrow differentiate into functional hepatocyte-like cells. J Clin Invest. 2002;109:1291-1302.

54. Vassilopoulos G, Wang PR, Russell DW. Transplanted bone marrow regenerates liver by cell fusion. Nature. 2003;422:901-904.

55. van Poll D, Parekkadan B, Cho $\mathrm{CH}$, et al. Mesenchymal stem cell-derived molecules directly modulate hepatocellular death and regeneration in vitro and in vivo. Hepatology. 2008;47:1634-1643.

56. Lagasse E, Connors H, Al-Dhalimy M, et al. Purified hematopoietic stem cells can differentiate into hepatocytes in vivo. Nat Med. 2000;6: 1229-1234

57. Brulport M, Schormann W, Bauer A, et al. Fate of extrahepatic human stem and precursor cells after transplantation into mouse livers. Hepatology. 2007;46:861-870.

58. Sato Y, Araki H, Kato J, et al. Human mesenchymal stem cells xenografted directly to rat liver are differentiated into human hepatocytes without fusion. Blood. 2005;106:756-763.

59. Martin GR. Isolation of a pluripotent cell line from early mouse embryos cultured in medium conditioned by teratocarcinoma stem cells. Proc Natl Acad Sci U SA. 1981;78:7634-7638.

60. Amit M, Carpenter MK, Inokuma MS, et al. Clonally derived human embryonic stem cell lines maintain pluripotency and proliferative potential for prolonged periods of culture. Dev Biol. 2000;227: 271-278.

61. Chinzei R, Tanaka Y, Shimizu-Saito K, et al. Embryoid-body cells derived from a mouse embryonic stem cell line show differentiation into functional hepatocytes. Hepatology. 2002;36:22-29.

62. Hamazaki T, Iiboshi Y, Oka M, et al. Hepatic maturation in differentiating embryonic stem cells in vitro. FEBS Lett. 2001;497:15-19.

63. Heo J, Factor VM, Uren T, et al. Hepatic precursors derived from murine embryonic stem cells contribute to regeneration of injured liver. Hepatology. 2006;44:1478-1486.

64. Anjos-Afonso F, Siapati EK, Bonnet D. In vivo contribution of murine mesenchymal stem cells into multiple cell-types under minimal damage conditions. J Cell Sci. 2004;117:5655-5664.

65. Hay DC, Zhao D, Ross A, Mandalam R, Lebkowski J, Cui W. Direct differentiation of human embryonic stem cells to hepatocyte-like cells exhibiting functional activities. Cloning Stem Cells. 2007;9: $51-62$.
66. Ishizaka S, Ouji Y, Yoshikawa M, Nakatani K. Derivation and characterization of hepatocytes from embryonic stem cells in vitro. Methods Mol Biol. 2006;330:387-399.

67. Alison MR, Poulsom R, Jeffery R, et al. Hepatocytes from non-hepatic adult stem cells. Nature. 2000;406:257.

68. Theise ND, Nimmakayalu M, Gardner R, et al. Liver from bone marrow in humans. Hepatology. 2001;32:11-16.

69. Zhang YN, Lie PC, Wei X. Differentiation of mesenchymal stromal cells derived from umbilical cord Wharton's jelly into hepatocyte-like cells. Cytotherapy. 2009;11:548-558.

70. Campard D, Lysy PA, Najimi M, Sokal EM. Native umbilical cord matrix stem cells express hepatic markers and differentiate into hepatocyte-like cells. Gastroenterology. 2008;134: 833-848.

71. Sáez-Lara MJ, Frecha C, Martín F, et al. Transplantation of human $\mathrm{CD}_{3}{ }^{+}$stem cells from umbilical cord blood to rats with thioacetamide-induced liver cirrhosis. Xenotransplantation. 2006;13: 529-535.

72. Qian H, Wang J, Wang S, Gong Z, Chen M, Ren Z, Huang S. In utero transplantation of human hematopoietic stem/progenitor cells partially repairs injured liver in mice. Int $J$ Mol Med. 2006;18: 633-642.

73. Lorenzini S, Gitto S, Grandini E, Andreone P, Bernardi M. Stem cells for end stage liver disease: How far have we got? World J Gastroenterol. 2008;14:4593-4599.

74. Chien CC, Yen BL, Lee FK, et al. In vitro differentiation of human placenta-derived multipotent cells into hepatocyte-like cells. Stem Cells. 2006;24:1759-1768.

75. Takahashi K, Yamanaka S. Induction of pluripotent stem cells from mouse embryonic and adult fibroblast cultures by defined factors. Cell. 2006;126:663-676.

76. Takahashi K, Tanabe K, Ohnuki M, et al. Induction of pluripotent stem cells from adult human fibroblasts by defined factors. Cell. 2007;131:861-872.

77. Yu J, Vodyanik MA, Smuga-Otto K, et al. Induced pluripotent stem cell lines derived from human somatic cells. Science. 2007;318: 1917-1920.

78. Si-Tayeb K, Noto FK, Nagaoka M, et al. Highly efficient generation of human hepatocyte-like cells from induced pluripotent stem cells. Hepatology. 2010;51:297-305.

79. Song Z, Cai J, Liu Y, et al. Efficient generation of hepatocyte-like cells from human induced pluripotent stem cells. Cell Res. 2009;19: $1233-1242$.

80. Aoi T, Yae K, Nakagawa M, et al. Generation of pluripotent stem cells from adult mouse liver and stomach cells. Science. 2008;321: 699-702.

81. Urbich C, Dimmeler S. Endothelial progenitor cells: Characterization and role in vascular biology. Circ Res. 2004;95:343-353.

82. Asahara T, Murohara T, Sullivan A, et al. Isolation of putative progenitor endothelial cells for angiogenesis. Science. 1997;275: 964-967.

83. Zengin E, Chalajour F, Gehling UM, et al. Vascular wall resident progenitor cells: A source for postnatal vasculogenesis. Development. 2006;133:1543-1551.

84. Nakamura T, Torimura T, Sakamoto M, et al. Significance and therapeutic potential of endothelial progenitor cell transplantation in a cirrhotic liver rat model. Gastroenterology. 2007;133:91-107.

85. Banas A, Teratani T, Yamamoto Y, et al. Adipose tissue-derived mesenchymal stem cells as a source of human hepatocytes. Hepatology. 2007;46:219-228.

86. Banas A, Teratani T, Yamamoto Y, et al. IFATS collection: In vivo therapeutic potential of human adipose tissue mesenchymal stem cells after transplantation into mice with liver injury. Stem Cells. 2008;26:2705-2712.

87. Ikeda E, Yagi K, Kojima M, et al. Multipotent cells from the human third molar: Feasibility of cell-based therapy for liver disease. Differentiation. 2008;76:495-505. 
88. Hisatomi Y, Okumura K, Nakamura K, et al. Flow cytometric isolation of endodermal progenitors from mouse salivary gland differentiate into hepatic and pancreatic lineages. Hepatology. 2004;39:667-675.

89. Miki T, Strom SC. Amnion-derived pluripotent/multipotent stem cells. Stem Cell Rev. 2006;2:133-142.

90. Ratajczak M, Zuba-Surma EK, Wysoczynski M, Ratajczak J, Kucia M. Very small embryonic-like stem cells: Characterization, developmental origin, and biological significance. Exp Hematol. 2008;36:742-751.

91. Harkness RD. Changes in the liver of the rat after partial hepatectomy. J Physiol. 1952;117:267-277.

92. Trotter NL. A fine structure study of lipid in mouse liver regenerating after partial hepatectomy. J Cell Biol. 1964;21:233-244.

93. Donato MF, Arosio E, Monti V, et al. Proliferating cell nuclear antigen assessed by a computer-assisted image analysis system in patients with chronic viral hepatitis and cirrhosis. Dig Liver Dis. 2002;34:197-203.

94. Freeman A, Hamid S, Morris L, et al. Improved detection of hepatocyte proliferation using antibody to the pre-replication complex: An association with hepatic fibrosis and viral replication in chronic hepatitis C virus infection. J Viral Hepat. 2003;10: 345-350.

95. Nowak MA, Bonhoeffer S, Hill AM, Boehme R, Thomas HC, McDade H. Viral dynamics in hepatitis B virus infection. Proc Natl Acad Sci U S A. 1996;93:4398-4402.

96. Rhim JA SE, Degen JL, Palmiter RD, Brinster RL. Replacement of diseased mouse liver by hepatic cell transplantation. Science. 1994;263:1149-1152.

97. Overturf K, al-Dhalimy M, Ou CN, Finegold M, Grompe M. Serial transplantation reveals the stem-cell-like regenerative potential of adult mouse hepatocytes. Am J Pathol. 1997;151:1273-1280.

98. Laconi E, Oren R, Mukhopadhyay DK, et al. Long-term, near-total liver replacement by transplantation of isolated hepatocytes in rats treated with retrorsine. Am J Pathol. 1998;153:319-329.

99. Li Y, Wan DF, Su JJ, et al. Differential expression of genes during aflatoxin $\mathrm{B}(1)$-induced hepatocarcinogenesis in tree shrews. World J Gastroenterol. 2005;10:497-504.

100. Pardal R, Clarke MF, Morrison SJ. Applying the principles of stemcell biology to cancer. Nat Rev Cancer. 2003;3:895-902.

101. Reya T, Morrison SJ, Clarke MF, Weissman IL. Stem cells, cancer, and cancer stem cells. Nature. 2001;414:105-111.

102. Hemmati HD, Nakano I, Lazareff JA, et al. Cancerous stem cells can arise from pediatric brain tumors. Proc Natl Acad Sci U S A. 2003;100:15178-15183.

103. Singh SK, Clarke ID, Terasaki M, et al. Identification of a cancer stem cell in human brain tumors. Cancer Res. 2003;63:5821-5828.

104. Singh SK, Hawkins C, Clarke ID, et al. Identification of human brain tumour initiating cells. Nature. 2004;432:396-401.

105. Collins AT, Berry PA, Hyde C, Stower MJ, Maitland NJ. Prospective identification of tumorigenic prostate cancer stem cells. Cancer Res 2005;65:10946-10951.

106. Al-Hajj M, Wicha MS, Benito-Hernandez A, Morrison SJ, Clarke MF. Prospective identification of tumorigenic breast cancer cells. Proc Natl Acad Sci U S A. 2003;100:3983-3988.

107. Lapidot T, Sirard C, Vormoor J, et al. A cell initiating human acute myeloid leukaemia after transplantation into SCID mice. Nature. 1994;367:645-648.

108. Houghton J, Stoicov C, Nomura S, et al. Gastric cancer originating from bone marrow-derived cells. Science. 2004;306:1568-1571.

109. O'Brien CA, Pollett A, Gallinger S, Dick JE. A human colon cancer cell capable of initiating tumour growth in immunodeficient mice. Nature. 2007;445:106-110.

110. Ricci-Vitiani L, Lombardi DG, Pilozzi E, et al. Identification and expansion of human colon-cancer-initiating cells. Nature. 2007;445:111-115.

111. Kim CF, Jackson EL, Woolfenden AE, et al. Identification of bronchioalveolar stem cells in normal lung and lung cancer. Cell. 2005;121:823-835.
112. Roskams T. Liver stem cells and their implication in hepatocellular and cholangiocarcinoma. Oncogene. 2006;25:3818-3822.

113. Esumi M, Aritaka T, Arii M, et al. Clonal origin of human hepatoma determined by integration of hepatitis B virus DNA. Cancer Res. 1986;46:5767-5771.

114. Ng I, Guan XY, Poon RT, Fan ST, Lee JM. Determination of the molecular relationship between multiple tumour nodules in hepatocellular carcinoma differentiates multi centric origin from intrahepatic metastasis. J Pathol. 2003;199:345-353.

115. Yamamoto T, Kajino K, Kudo M, Sasaki Y, Arakawa Y, Hino O. Determination of the clonal origin of multiple human hepatocellular carcinomas by cloning and polymerase chain reaction of the integrated hepatitis B virus DNA. Hepatology. 1999;29:1446-1452.

116. Zhang SH, Cong WM, Wu MC. Focal nodular hyperplasia with concomitant hepatocellular carcinoma: A case report and clonal analysis. J Clin Pathol. 2004;57:556-559.

117. Alison MR. Liver stem cells: implications for hepatocarcinogenesis. Stem Cell Rev. 2005;1:253-260.

118. Gournay J, Auvigne I, Pichard V, Ligeza C, Bralet MP, Ferry N. In vivo cell lineage analysis during chemical hepatocarcinogenesis in rats using retroviral-mediated gene transfer: evidence for dedifferentiation of mature hepatocytes. Lab Invest. 2002;82: 781-788.

119. Bralet MP, Pichard V, Ferry N. Demonstration of direct lineage between hepatocytes and hepatocellular carcinoma in diethylnitrosaminetreated rats. Hepatology. 2002;36:623-630.

120. Suzuki A, Zheng YW, Kaneko S, et al. Clonal identification and characterization of self-renewing pluripotent stem cells in the developing liver. J Cell Biol. 2002;156:173-184.

121. Lowes KN, Croager EJ, Olynyk JK, Abraham LJ, Yeoh GC. Oval cell-mediated liver regeneration: Role of cytokines and growth factors. J Gastroenterol Hepatol. 2003;18:4-12.

122. Evarts RP, Hu Z, Omori N, Omori M, Marsden ER, Thorgeirsson SS Precursor-product relationship between oval cells and hepatocytes: Comparison between tritiated thymidine and bromodeoxyuridine as tracers. Carcinogenesis. 1996;17:2143-2151.

123. Solt D, Medline A, Farber E. Rapid emergence of carcinogen-induced hyperplastic lesions in a new model for the sequential analysis of liver carcinogenesis. Am J Pathol. 1977;88:595-609.

124. Dumble M, Croager EJ, Yeoh GC, Quail EA. Generation and characterization of p53 null transformed hepatic progenitor cells: Oval cells give rise to hepatocellular carcinoma. Carcinogenesis. 2002;23:435-445.

125. Yang Z, Ho DW, Ng MN, et al. Significance of $\mathrm{CD} 90^{+}$cancer stem cells in human liver cancer. Cancer Cell. 2008;13:153-166.

126. Libbrecht L, Roskams T. Hepatic progenitor cells in human liver diseases. Semin Cell Dev Biol. 2002;13:389-396.

127. Ruck P, Xiao JC, Pietsch T, Von Schweinitz. D, Kaiserling E. Hepatic stem-like cells in hepatoblastoma: Expression of cytokeratin 7 , albumin and oval cell associated antigens detected by OV-1 and OV-6. Histopathol. 1997;31:324-329.

128. Libbrecht L, Desmet V, Roskams T. Stages of normal and aberrant intrahepatic bile duct development in a mixed hepatoblastoma. Histopathology. 2003;42:618-620.

129. Theise ND, Yao JL, Harada K, et al. Hepatic 'stem cell' malignancies in adults: Four cases. Histopathology. 2003;43:263-271.

130. Zhang F, Chen X-P, Zhang W, et al. Combined hepatocellular cholangiocarcinoma originating from hepatic progenitor cells: Immunohistochemical and double-fluorescence immunostaining evidence. Histopathology. 2008;52:224-232.

131. Drobinskaya I, Linn T, Saric T, et al. Scalable selection of hepatocyteand hepatocyte precursor-like cells from culture of differentiating transgenically modified murine embryonic stem cells. Stem Cells. 2008;26:2245-2256.

132. Ma S, Lee TK, Zheng BJ, Chan KW, Guan XY. CD133p HCC cancer stem cells confer chemoresistance by preferential expression of the Akt/PKB survival pathway. Oncogene. 2008;27:1749-1758. 
133. Huff CA, Matsui WH, Douglas Smith B, Jones RJ. Strategies to eliminate cancer stem cells: clinical implications. Eur J Cancer. 2006;42:1293-1297.

134. Schmelzer E, Zhang L, Bruce A, et al. Human hepatic stem cells from fetal and postnatal donors. J Exp Med. 2007;204: 1973-1987.

135. Rountree CB, Barsky L, Ge S, Zhu J, Senadheera S, Crooks GM. A CD133-expressing murine liver oval cell population with bilineage potential. Stem Cells. 2007;25:2419-2429.

136. Rountree CB, Ding W, He L, Stiles B. Expansion of CD133 expressing liver cancer stem cells in liver specific PTEN deleted mice. Stem Cells. 2008;27:290-299.
137. Spira AI, Carducci MA. Differentiation therapy. Curr Opin Pharmacol. 2003;3:338-343.

138. Sharova LV, Sharov AA, Piao Y, et al. Global gene expression profiling reveals similarities and differences among mouse pluripotent stem cells of different origins and strains. Dev Biol. 2007;307:446-459.

139. Noël D, Caton D, Roche S, et al. Cell specific differences between human adipose-derived and mesenchymal-stromal cells despite similar differentiation potentials. Exp Cell Res. 2008;314:1575-1584.

\section{Publish your work in this journal}

Stem Cells and Cloning: Advances and Applications is an international, peer-reviewed, open access journal. Areas of interest in stem cell research include: Embryonic cell stems; Adult stem cells; Blastocysts; Cordblood stem cells; Stem cell transformation and culture; Therapeutic cloning; Umbilical cord blood and bone marrow cells; Laboratory, animal and human therapeutic studies; Philosophical and ethical issues related to stem cell research. This journal is indexed on CAS. The manuscript management system is completely online and includes a quick and fair peer-review system. Visit http://www.dovepress.com/testimonials. php to read real quotes from published authors.

Submit your manuscript here: http://www.dovepress.com/stem-cells-and-cloning-advances-and-applications-journal 